\title{
A experiência religiosa e a institucionalização da religião
}

\author{
ANTONIO GOUVÊA MENDONÇA
}

$\mathrm{E}$ M 10 DE ABRIL de 1974 falecia em Paris, aos 76 anos, Roger Bastide, pioneiro da Sociologia da Religião no Brasil. O serviço fúnebre, oficiado na capela protestante da Clínica de Maisons-Laffite pelo pastor Raymond Leenhardt, do Instituto de Línguas Orientais da Sorbonne, foi acompanhado por "tambores religiosos, alternando toques brasileiros e africanos, reunindo assim numa só homenagem as religiões que sem dúvida formavam o pano de fundo de todo o pensamento de Roger Bastide, homem e sociólogo: o protestantismo e os cultos afro-brasileiros" .

É extraordinário que um protestante de tradição calvinista, formado, portanto, no rigor dogmático e ético da Reforma franco-suíça, com seu culto extremamente intelectual e, diríamos mesmo, desencantado e quase secular, beirando o profano no sentido puramente técnico deste termo, tivesse uma cerimônia fúnebre de tal natureza. Pois que os tambores afros não representavam outra coisa se não o mistério de cultos em que os deuses se mostram de maneira diferente, não enquadrados em dogmas ou éticas institucionais.

Talvez um trecho do sermão fúnebre do pastor Leenhardt nos ajude a entender a personalidade de Bastide, personalidade que o levou a perseguir tenazmente a percepção do sagrado nas religiões. Disse o pregador: "Sua grandeza d'alma se desenvolveu estreitamente ligada ao torrão cevenol, e a mensagem evangélica trouxe ao vigor de seu pensamento uma abertura, um equilíbrio entre espírito e coração..."2.

Há, neste trecho do sermão, uma chave para entender a razão do porque um protestante, formado e preso a uma tradição religiosa fortemente instituída, pode abrir-se para religiões sem dogmas e a-éticas e praticamente semi-institucionalizadas, ou mesmo anteriores a qualquer institucionalização.

O pastor Leenhardt faz uma ligação entre a mensagem evangélica que Bastide recebera na sua formação na região de Cévennes, na França, teatro de terrível guerra religiosa provocada pela revogação do Edito de Nantes, em 1685, por Luís XIV, e o equilíbrio entre o espírito, aqui a razão, e o coração, isto é, a emoção. Pode-se inferir que a tradição de lutas religiosas pode introduzir numa cultura religiosa minoritária fortes traços emocionais que se superpõem à religiosidade dogmática e mesmo intelectual.

No caso de Bastide, então, o peso do Evangelho, a narrativa dos atos de Jesus de Nazaré, antecede, não somente no tempo mas também no conceito, a 
progressiva institucionalização do Cristianismo. Se isto é verdade, embora não me lembre de nenhuma referência feita por ele, ou por alguém a respeito dele, que autorize o que estou dizendo, parece que Bastide se alinha, embora de forma absolutamente distinta, de um lado, aos teólogos liberais do século XIX e, de outro, aos místicos que viveram muito próximos, mas fora da igreja.

Os chamados liberais evangélicos buscavam, antes de qualquer outra coisa, o modelo de beleza ética encarnado em Jesus de Nazaré, historicamente comprovado, e os místicos, uma contínua aproximação não mediada do mesmo Senhor, tido como existente e vivo, mas não sujeito aos limites do dogma e da ética institucionais. Se os liberais buscavam provar a historicidade de Jesus, ao mesmo tempo livrando-o, como dizia Harry Emerson Fosdick ${ }^{3}$, das teologizações já presentes nos textos evangélicos, os místicos buscavam Jesus pelo atalho da intuição não discursiva. Não é exagero dizer que, em última instância, tanto os liberais como os místicos prescindiam da instituição religiosa, neste caso a igreja, como necessária para a vida cristã. Alguns liberais protestantes foram hostilizados pela ortodoxia, mas a história registra que o padre Alfred Loisy (1857-1949), líder do movimento modernista católico, foi excomungado em 1908 ou 1909 pelas idéias por ele expostas no seu célebre livro L'Evangile et l'Eglise, publicado em 1902. Neste livro, Loisy exara a célebre frase "Jesus pregou o Reino e veio a Igreja"4.

Quanto aos místicos, pela própria natureza de sua experiência religiosa, difícil de ser posta em forma discursiva e sistemática, em geral não incomodavam a igreja. Regra geral, têm uma trajetória paralela à vida da igreja, não contribuindo diretamente para a sistemática, mas oferecendo exemplos notáveis para a vida cristã.

Em suma, o que estou querendo dizer é que esta questão da experiência religiosa, ou a visão e a experimentação do sagrado como sendo algo exclusivo de religiões exóticas e primitivas, não prevalece hoje no estudo das religiões. A história da vida institucional do Cristianismo mostra, em todas as suas diversas manifestações, que a experiência religiosa, seja individual ou coletiva (neste caso, grupos ou comunidades místicas em fase às vezes pré-institucional), está sempre presente provocando retornos e simplificações institucionais.

A intenção deste texto é demonstrar que entre a experiência religiosa e a institucionalização da religião há um caminho às vezes curto, às vezes longo, que em certos casos se completa e noutros não. Para isso, dedicarei espaço tanto para as teorias sobre a experiência religiosa como para os processos de institucionalização e suas formas de diferenciação por estágios.

\section{As formas do sagrado}

O subtítulo em si já denota uma dificuldade lógica ou um paradoxo de conceito, pois que o sagrado absolutamente a priori não pode ter formas, pois que se as tivesse seria objeto de conhecimento sensível. E não o é. A experiência do sagrado fundamenta-se num fenômeno, numa aparição. Ora, um fenômeno, ou uma "aparição" como preferem os existencialistas, por si só, ou por definição, 
já é uma limitação do ser, não é todo o ser. O sagrado da experiência não se mostra por inteiro, pois que se isto ocorrer já não é mais um sagrado, não é um deus.

Comecei falando em Roger Bastide e vou caminhar por um pouco com ele nesta questão, embora na ordem dos autores que pretendo examinar, ele não seja o primeiro. Começo por Bastide pelo fato de ter sido ele o criador de um conceito que se tornou clássico em Ciências da Religião: o conceito de "sagrado selvagem". Além desse conceito, Bastide criou o de "cisão" (coupure) que pode nos ajudar a compreender outras questões, como o choque ético entre culturas religiosas diferentes e a possibilidade de viver uma religião sem os compromissos institucionais.

Tratemos primeiro do tema do "sagrado selvagem", um dos textos mais ricos de Bastide e que traz em si uma teoria consistente a respeito das variações da experiência do sagrado nas religiões. O livro, que traz o título do seu último capítulo ("Le sacré sauvage") publicados entre 1931 e 1973. O livro saiu em 1977 por iniciativa de seu amigo Henri Desroche, de quem falarei mais adiante.

O capítulo sobre o "sagrado selvagem" parte de recorrências do sagrado no sonho, nos mitos, na prece, no milenarismo do candomblé da Bahia. Neste ponto, Bastide parte de seus conhecidos pontos de vista psicológicos e psicanalíticos sobre a religião. Segundo ele, o homem é uma "máquina de fazer deuses" que, à medida em que o sagrado se torna "frio" ( froid) nas instituições religiosas (igrejas) recria o sagrado "quente" (chaud), que ele chama de "sagrado selvagem”. A irrupção do sagrado constitui um ponto de efervescência, un point d'orgue, isto é, uma suspensão na cadência musical (caldeirão).

Émile Durkheim afirmara que a religião surge nos estados de efervescência social, em que o tempo sagrado interrompe o tempo profano das atividades sociais e econômicas. Bastide conclui, a partir daí, que os estados de efervescência religiosa não são duráveis.

Após a efervescência há uma queda do fervor sociológico. A religião já instituída desenvolve-se a partir dessa queda "como gestora da experiência do sagrado".

Essa gestão do sagrado pela igreja, diz Bastide, ao contrário do que se pode pensar, tem um aspecto ou valor positivo, pois que assegura sua continuidade sob a forma de uma comemoração, de uma "lembrança" ensurdecida, de uma memória ou tradição. Por outro lado, porém, a instituição, através de sua liturgia burocratizada, impede que o sagrado volte em inovações perigosas, e também com outro discurso, um discurso diferente do aceito pela ortodoxia. A liturgia padrão, assim como o discurso certo da ortodoxia, aprisiona o sagrado, transformando-o de selvagem em dominado.

Repetindo o que eu disse de início, mas agora com as próprias palavras de Bastide, "toda igreja constituída tem, sem dúvida, seus místicos, mas ela desconfia deles, ela lhes delega seus confessores e seus diretores para dirigir, canalizar, 
controlar seus estados extáticos, quando ela não os prende em algum convento que seus gritos de amor perdido não possam perfurar". Os movimentos de refor$\mathrm{ma}$, as heresias, os messianismos e os milenarismos são expressões sociais do desejo de volta a um passado vibrante e efervescente de "deuses sonhados". Daí, todos esses delírios místicos que, de vez em quando, abalam o equilíbrio das igrejas.

Os católicos sonhariam com Joaquim de Fiore e, após ele, com o reino do Espírito Santo que substituiria os reinos da lei e da graça, um reino messiânico de guerra contra a opressão, como exemplo a Teologia da Libertação, ou um reino de liberdade e de paz, como no movimento de renovação. Em ambos os casos, algo que, embora no âmbito da igreja, manteria boa margem de autonomia a partir da liberação, ao menos parcial do sagrado instituído ou dominado. No protestantismo, os despertamentos, como o do século XIX, liberaram o sagrado para sacudir os pecadores impenitentes, para em seguida subordiná-los à ética do trabalho e do progresso sob a égide da moral vitoriana; os pentecostalismos, por sua vez, substituem a religião do livro, sistemática e racional, pela inspiração divina com parcial descontrole do sagrado.

Neste ponto, é sugestivo que apontemos as diferenças entre o catolicismo e o protestantismo, no que tange ao controle do sagrado. No catolicismo, os mecanismos de controle do sagrado são mais elásticos. Raramente o rigorismo institucional se preocupa com os místicos. Estes, embora vivam à sombra do sagrado como tal, portanto desteologizado, vivem ao mesmo tempo sob o pálio da igreja à qual confessam. Quando, por um motivo ou outro, propõem inovações, são submetidos às regras de uma ordem. Se revolucionários, vão aos poucos também sendo submetidos à hierarquia institucional. Raramente a Igreja Católica exclui os que pretendem liberar o sagrado; antes, os envolve com seu pálio e os transforma em agentes eficientes da sua continuidade, como diz Bastide.

No protestantismo, ao contrário, os inovadores, os reformadores, todos aqueles que se esforçam por voltar a um sagrado mais "quente", são logo excluídos. Como o sistema, ou princípio, de ordenação tornou-se legal ou burocrático, independente da transmissão do carisma, os dissidentes formam logo outras instituições e consagram seus pastores sem outras formalidades. Além disso, a ausência de um centro exclusivo de poder e de gestão do sagrado permite o surgimento circunstancial de confissões de fé que sustentam as diversas denominações. Para simplificar e exemplificar, poderíamos dizer que as tradições surgidas diretamente da Reforma, nas suas vertentes principais que foram a anglicana, a luterana e a calvinista ou reformada propriamente dita, mantendo, ou procurando manter, seus elementos religiosos fundantes, viram e continuam vendo sucessivas e múltiplas dissidências que se propõem a recuperar um sagrado mais "quente".

Nesse permanente movimento de aprisionamento e liberação parcial do sagrado, numa seqüência dialética de afirmação e negação, pode-se depreender uma lei que rege o caminho da experiência religiosa (experiência do fenômeno do sagrado) à institucionalização da religião e vice-versa: quanto mais rígida e 
sujeita a doutrinas estabelecidas e consolidadas for uma instituição religiosa, mais sujeita estará a divisões ocasionadas pela necessidade de liberação do sagrado. A história mostra que, das tradições cristãs, a vertente mais sujeita a divisões é a calvinista, ou reformada propriamente dita, pela simples razão de que é a que mais produziu confissões ou símbolos de fé. No universo da Reforma, essa tendência caminha inversamente na medida em que documentos simbólicos escasseiam ou são ausentes: os luteranos com sua Confissão de Augsburgo e os anglicanos, em que um corpo doutrinário está ausente. Mesmo que nos lembremos da Lei dos 39 artigos de religião, promulgada por Isabel I, assim como do Livro de Oração Comum, o fato é que aquela só é conservada como testemunho histórico e este, como o diretório da devoção e do culto. Não têm valor dogmático.

Vale aqui relembrar o surto teológico havido no mundo protestante de meados do século passado: o movimento teológico da "morte de Deus". Dos grandes embates entre liberais ou modernistas e conservadores, acentuados pela Guerra e o início da Guerra Fria, surgiu um grande desapontamento com respeito às igrejas. Elas tinham encastelado Deus a tal ponto que ele se tornou impotente diante das necessidades do mundo. Elas haviam se transformado em "túmulos de Deus", asilo de um Deus morto. Foram protagonistas desta teologia Thomas J. J. Altizer e William Hamilton ("Teologia da morte de Deus") ${ }^{6}$ e, controvertidamente arrolados, como diz Gibellini ${ }^{7}$, Gabriel Vahanian ${ }^{8}$, Bispo J. A. T. Robinson ${ }^{9}$ e Harvey $\operatorname{Cox}^{10}$. Não se tratava, como parece, de um surto de ateísmo, da consciência de que Deus aprisionado nas igrejas e na cultura perdera relevância. Para os teólogos da "morte de Deus", a excessiva transcendência de Deus, além de seu aprisionamento institucional, deixava-o distante e inoperante. Para Vahanian, por exemplo, seria necessário lembrar que o Deus transcendente é também imanente, bem na linha dos liberais evangélicos, dos místicos e dos messianismos políticos.

Embutida ou paralela à teologia da morte de Deus estava a da secularização, principalmente em Harvey Cox. Para estes teólogos, a secularização é uma purificação dos entraves do mito, da metafísica e da religião ${ }^{11}$.

O fato é que o movimento teológico da morte de Deus, da secularização, assim como da política, produziu grande abalo nas igrejas protestantes no período pós-Segunda Guerra, do movimento ecumênico e da Guerra Fria.

Até aqui tentei expor a teoria bastidiana que nos ajuda a compreender e a explicar os movimentos e as mutações no interior das religiões instituídas. Voltarei a essa questão mais adiante.

Vou dividir a parte que se segue em três momentos daquilo que chamamos de experiência religiosa: a experiência fundante, que Mircea Eliade chama de hierofania, a institucionalização ou a formação da religião e, por fim, os mecanismos de transformação e manutenção da instituição. Para isso, recorrerei ao auxílio dos clássicos das Ciências da Religião. 


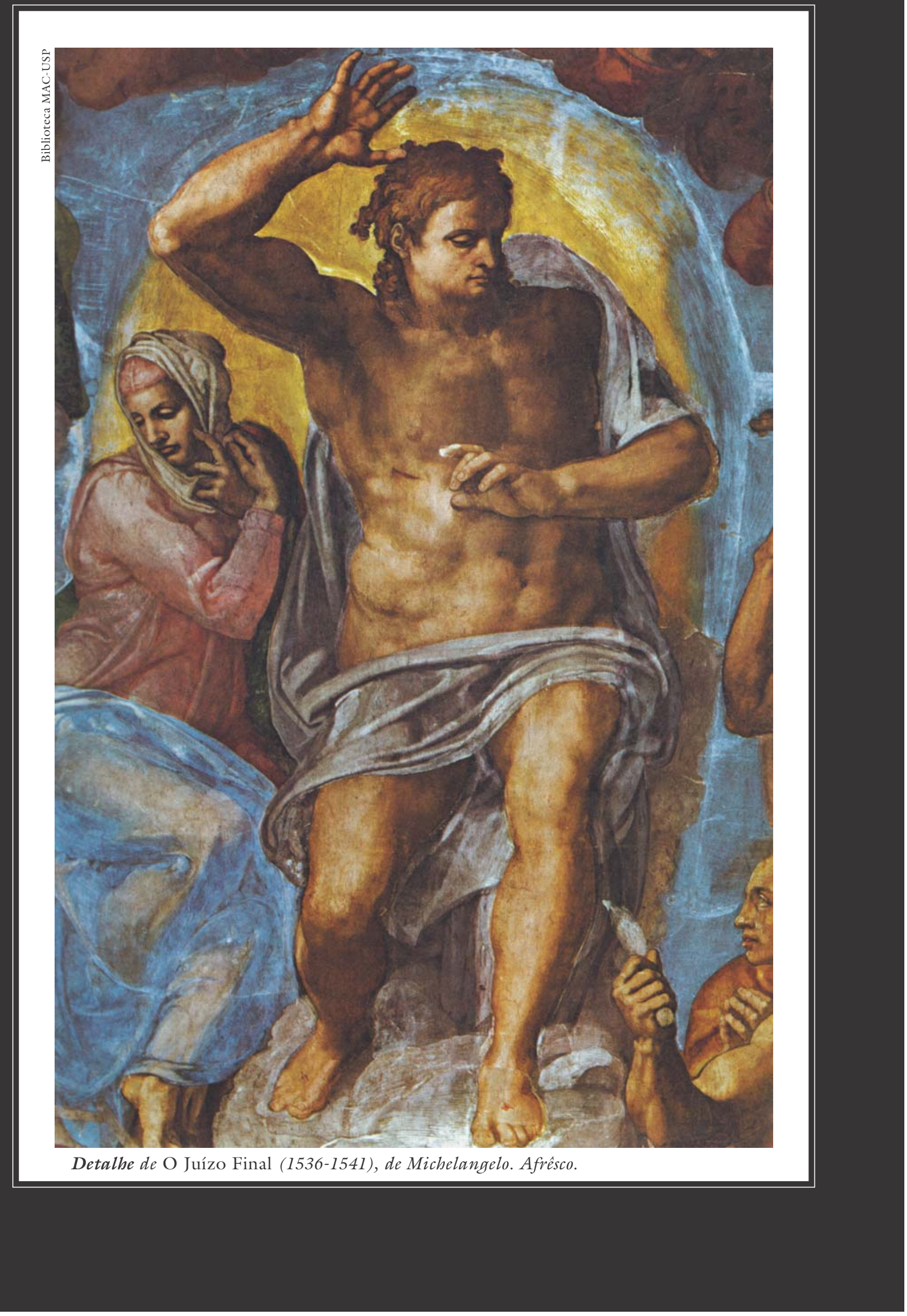




\section{A experiência fundante da religião}

A experiência fundante ou modificadora da religião, chamada na filosofia e na história das religiões de hierofania, foi magistralmente trabalhada por Mircea Eliade. É um tema considerado por ele em toda a sua vasta obra, mas o principal está em Tratado de história das religiões (1970). Eliade pretende, nesse trabalho, chegar normalmente à definição do fenômeno da religião sem a necessidade de começar pelos a priori da essência da religião. O estudo da hierofania, ou dos grupos de hierofanias, nos leva a refletir sobre a morfologia do sagrado.

Cada tipo de hierofania, entendida esta como a irrupção do sagrado, cada uma ao seu modo, permite uma dada e diferente aproximação do sagrado. A hierofania, com poucas exceções, é um epifenômeno que se apresenta a um indivíduo e constitui nele uma experiência fundante ou transformadora, ou mesmo mantenedora de uma forma de religião. No primeiro caso, temos os indivíduos fundadores de religiões; no segundo, os profetas que pregam a volta às origens da religião instituída ou a correção de seus desvios e, por último, o reforço do sagrado dominado, cujos exemplos melhores são as aparições da Virgem que estabelecem romarias a locais sagrados. Neste último caso, a "aparição" do sagrado que se revela em um de seus aspectos, mas que traz em si, por definição, a totalidade do seu ser (no caso da Virgem que se revela por inteira), a religião instituída apressa-se em limitar ou especializar seu poder de modo a dominá-lo. Toda limitação (regulamentação) da aparição ou epifenômeno significa colocálo sob custódia.

Na rota conceitual de Eliade, vamos tentar, limitando-nos ao judeu-cristianismo, dar alguns exemplos de hierofanias narradas na Bíblia e que nos ajudam a entender melhor o que estamos vendo em sua teoria.

Vamos, didaticamente, partir da hierofania fundante da religião do Antigo Testamento: Moisés e a sarça ardente. Pastor, Moisés apascentava o rebanho de seu sogro quando, chegando a um monte, viu uma sarça que ardia mas não se consumia. Curioso, Moisés tenta se aproximar, mas Deus o advertiu que permanecesse à distância e se revela como o Deus de seus pais e faz promessas de salvamento para o seu povo (hebreus, escravos no Egito). As promessas deviam ser transmitidas ao povo, mas em nome de quem? Deus responde: "Eu sou o que sou”. Diga a eles: o "Eu sou mandou” (Ex. 3, 1-6).

Moisés não viu a Deus, não pôde fazê-lo porque foi impedido de se aproximar, mas viu o fogo, símbolo do sagrado, centro mesmo da hierofania. A voz se identificava com o SER absoluto de Deus: "Eu sou”, aquele que é a plenitude do ser e, por isso, não tem nome porque o nome por si já limita o ser. Mas este pleno "Eu sou" apresenta-se limitado a Moisés porque o sujeito da hierofania é incapaz de apreender o "Eu sou” pleno. O que Moisés vê? Vê o fogo que, com seu poder extremamente móvel, imprevisível, não dominado, que não se sabe de onde vem nem para onde vai e que não consumia a sarça, como parte do sagrado que assim se revelava. 
Eliade nos chama a atenção para a recorrência do fogo nas mais diversas culturas e religiões para significar, particularmente, a energia ao mesmo tempo criadora e sustentadora. Diz Ernst Cassirer que o fogo é uma metáfora radical. Heráclito de Éfeso, segundo Diógenes Laércio, afirmava que o fogo é o princípio de todas as coisas, não da fixidez, mas da mutação, sendo capaz de fazer passar a matéria de um estado a outro. O fogo é o sujeito do movimento do mundo, inteligente e divino ${ }^{12}$.

A experiência de Moisés, essa hierofania do fogo no monte de Deus, o Horebe, autorizou-o a falar ao povo em nome de Deus. O discurso de Moisés daí em diante parte dessa experiência e segue na direção da criação de uma religião. Num outro passo (Ex. 33, 12-23), Moisés, desejando a confirmação de que Deus o acompanhava na pesada missão de conduzir o povo à Terra Prometida, roga a Deus que lhe mostre sua glória. Não pôde ver a face de Deus, o que seria conhecêlo por inteiro, mas "sentiu” sua presença (glória) e "viu-o" pelas costas.

Os profetas do Antigo Testamento desempenharam a função de guardas da memória e da tradição diante de uma religião sacerdotal já instituída e confundida com um estado hierocrata, assim como de arautos de eventos desastrosos futuros por causa da infidelidade e dos desvios de reis sagrados e sacerdotes. Todos eles partiam de experiências pessoais hierofânicas com Deus. Basta citar o episódio do chamamento de Isaías (Is. 6, 1-8). No caso das hierofanias de Moisés, temos experiências religiosas fundantes e, no dos profetas, hierofanias de conservação da religião instituída.

Voltemos a mais uma hierofania do fogo. Trata-se de uma hierofania coletiva e transformadora. O Cristianismo começa de fato a ser uma religião com o Pentecostes, embora ainda como uma seita do Judaísmo.

A narrativa de Atos 2, 1-43 constitui-se na hierofania do Espírito. Ela se distingue de outras, como as de Moisés, porque foi testemunhada por uma comunidade de pessoas e não por um indivíduo. Liga-se a uma promessa de Jesus aos seus seguidores como aparece no Evangelho de João $(16,17)$. Os elementos dessa hierofania, como sempre composta por homens e elementos da natureza, são o fogo e o vento de um lado, e Pedro, os onze e demais circunstantes de outro.

A metáfora do fogo como elemento principal do mito hierofânico do Pentecostes pode significar, com toda a sua riqueza, o sagrado como o logos que cria, mantém, transforma, purifica e está presente em todas as coisas. É princípio de transformação; é movimento, mas movimento não previsível porque se processa segundo o destino. É um poder que vem de fora do mundo, mas que tudo penetra, conserva e transforma e cuja trajetória é imprevisível para os homens. A metáfora radical do fogo introduz, no interior mesmo dos elementos da hierofania do Pentecostes, uma conseqüência direta: a distribuição de línguas que unifica o discurso querigmático de Pedro. Fecha-se, assim, o círculo simbólico da hierofania do Pentecostes: um poder vindo de fora do mundo, um sagrado universal, fora do círculo do Judaísmo, mas que remete à sarça ardente que fascinou Moisés no 
Horebe e que cumpriria a promessa do Evangelho (parácleto) e, ao mesmo tempo, o compromisso de romper o círculo religioso a que se achava restrita a "mensagem nova" ("até os confins da terra"). Rompem-se, ao mesmo tempo, os círculos geográfico e religioso-cultural.

É significativo para o estudioso da experiência religiosa fundante que o mistério do sagrado, no mito cujo centro é o fogo, conserva aquela qualidade essencial descrita por Rudolf Otto ${ }^{13}$ : é o mysterium tremendum, porque não se sabe de onde vem nem para onde vai.

Outro elemento da natureza que aparece na narrativa do Pentecostes é o vento e tem um sentido complementar ao fogo no conjunto dessa hierofania do Espírito. O Evangelho de João $(3,8)$ diz assim: "O vento sopra onde quer e ouves o seu ruído, mas não sabes de onde vem nem para onde vai. Assim acontece com todo aquele que nasce do Espírito" (Bíblia de Jerusalém).

Agora, são quatro os elementos da hierofania: o fogo, o vento, o dom de línguas e o discurso fundante do Apóstolo entendido por dezenas de falantes de outras línguas.

O sentido desse mito hierofânico deve ser buscado, como de regra, nas condições sócio-históricas dos seus sujeitos. Eram eles pescadores, artesãos ou pequenos funcionários públicos oprimidos entre as elites politicamente comprometidas da Palestina e o poderio romano. De um lado, o monoteísmo judaico dos sacerdotes e levitas, ou legistas, e de outro, o politeísmo helenizado dos romanos. Nada restava ao pequeno grupo de oprimidos, seguidores de um mestre que, ao mesmo tempo, mantinha diplomaticamente à distância o opressor político e demolia a elite sacerdotal comprometida e sua religião, a não ser proclamar-se detentor de um poder universal outorgado de modo espetacular pelo mestre sacrificado pelo conluio dos dois poderes político-religiosos opressores. Assim, uma pequena seita do Judaísmo rompe seus estreitos limites geográficos, sociais e políticos, para dois séculos e meio depois se transformar na religião mais poderosa do mundo antigo, uma religião do Império.

O evento mítico, ao mesmo tempo transformador e fundante, transformador quanto ao Judaísmo e fundante quanto ao Cristianismo, "racionaliza" ou "justifica" a tese de origem sobrenatural da igreja, sua universalidade e pobreza original. O livro de Atos narra outros eventos hierofânicos miraculosos, como a nova manifestação de forças da natureza na libertação de Paulo e Silas da prisão de Filipos (Atos 16, 26), para legitimar a hierofania e, como sugere Eliade, corrigir rotas e consolidar princípios da nova religião. Mas, o Pentecostes, como tal, não se repetiu nos registros do Novo Testamento. Mesmo a Reforma não abalou esse fundamento institucional do Cristianismo. Fixaram-se somente os ritos e as doutrinas em torno deles.

Concluindo estas considerações a respeito da experiência bíblica do Pentecostes, é oportuno lembrar a nossa insistência em recusar o pentecostalismo como um continuum em relação ao protestantismo histórico, como uma espécie de 
popularização das igrejas da Reforma. Em primeiro lugar, como bem frisou o teólogo da cultura Paul Tillich, o popular não é da índole do protestantismo, ele não é uma religião de massas. Em segundo lugar, e mais relevante neste caso, é a diferença fundamental entre o protestantismo e os pentecostalismos: para estes, o Pentecostes se repete infinitamente pelo derramamento do Espírito ao passo que, para aquele, o Pentecostes não se repete porque o Espírito veio, segundo a promessa do Evangelho, e ficou com a Igreja, mantendo-a e renovando-a sempre. Aliás, este é o princípio também de todo o Cristianismo tradicional.

Voltemos um pouco atrás a fim de completar esta teoria sobre as hierofanias bíblicas. A hierofania de Moisés no Horebe é fundante no Judaísmo; a do Pentecostes é transformadora em relação ao Judaísmo e fundante face ao Cristianismo. Mas, entre elas há outra que não pode ser omitida: a epifania de Deus em Cristo, Deus conosco. Deste modo, a epifania é fundante em relação ao Cristianismo e o Pentecostes, uma transformação da epifania e a institucionalização da igreja cristã. Vemos então que o mesmo sagrado está presente nos três momentos fundantes e transformadores da religião.

\section{O sagrado instituinte e o sagrado instituído}

A experiência religiosa do sagrado, portanto, a rigor teorizada por Eliade no seu conceito e análise das hierofanias, é fundante e transformadora da religião, podendo ser ambas as coisas ao mesmo tempo. Mas, também pode ser conservadora, mantendo no interior mesmo da religião aquela dinâmica, ou ebulição, necessária para que continue viva. Mesmo que as religiões acreditem permanecer como tais porque se remetem sempre à sua tradição e memória, por intermédio do seu instrumento clerical e sacerdotal, elas estão sempre se modificando através de outro instrumento que é o profetismo constestatário e corretivo que há no seu interior.

Para que possamos prosseguir e atingir nosso objetivo será necessário, neste ponto, estabelecer alguns parâmetros teórico-conceituais. Tentemos, para isso, distinguir religião de instituição religiosa, ou se preferirmos maior clareza, de igrejas.

Diversos estudiosos da história das religiões ou, de maneira mais particular, das ciências da religião, procuram distinguir religião de igreja, ou religião instituída. Antes e depois de Bastide, a distinção aparece com insistência. Nenhum historiador, filósofo ou cientista da religião apresenta igreja ou instituição religiosa, ao menos de maneira direta, como seu objeto de estudo. A instituição aparece como simples referência em alguns casos. Especificamente, o estudo da instituição religiosa como tal estaria noutro campo de estudos, como a Sociologia das Instituições, por exemplo.

Falamos em antes e depois de Bastide, porque foi ele que, ao escrever o seu clássico texto "O sagrado selvagem”, definiu com clareza todo o processo dialético que há entre o sagrado não dominado, o sujeito-objeto da experiência religiosa, 
e o sagrado dominado da instituição religiosa. Embora a sociologia de Bastide nada tenha a ver com as teorias de Max Weber, neste caso, as que dizem respeito aos tipos puros ou ideais, não há como não observar que ambos os conceitos de Bastide, o de sagrado dominado e não dominado, são tipos puros ou ideais. Não há, na realidade, nenhum sagrado absolutamente dominado, como também não há um sagrado absolutamente selvagem. Nenhuma instituição ou igreja pode, com seus dogmas ou confissões, engessar completamente o sagrado: ele guardará sempre suas franjas de mistério pois, caso contrário, deixará de ser sagrado; um deus conhecido não é mais um deus, disse alguém. Por outro lado, a experiência religiosa, seja íntima ou objetiva, neste caso hierofânica, jamais capta o sagrado por inteiro pela mesma razão anterior.

O que há é um espaço mais ou menos desorganizado, ou às vezes mais ou menos organizado, entre a experiência religiosa, espaço da religião propriamente dita, e a religião instituída, ou igreja. Este espaço pulsa antes da instituição ou no interior dela como um elemento regulador entre sua inércia e dinâmica.

Um discípulo e companheiro de Bastide na Sorbonne, Henri Desroche (1914-1994), nos ajudará a tornar mais clara esta teoria. No seu livro pouco conhecido e quase nunca citado, Sociologia da esperança (1985), ele consagra a "Introdução" ao que ele chama de "milagre da corda". O milagre da corda, recorrente na história das religiões, aparecendo em vários lugares e autores, inclusive em Mircea Eliade, consiste no seguinte: um xamã, faquir, ou malabarista, lança uma corda para o ar e ela, espiralando para cima, fica firme e ereta ao ponto de permitir que ele suba por ela. Está presa firmemente em algum lugar acima, em algo que não se sabe o que é, mas que oferece ao xamã ou seu secretário confiança para subir por ela.

Desroche serve-se deste mito da corda para ir desenvolvendo-o em outras direções de acordo com seus objetivos no livro. Mas, como o mito permite outros usos e interpretações, servimo-nos dele para o nosso próprio fim: o do mistério do sagrado. Lançar a corda e subir por ela numa aproximação infinita, porque Roger Bastide caminha pelas ruas de São Paulo em 1944.

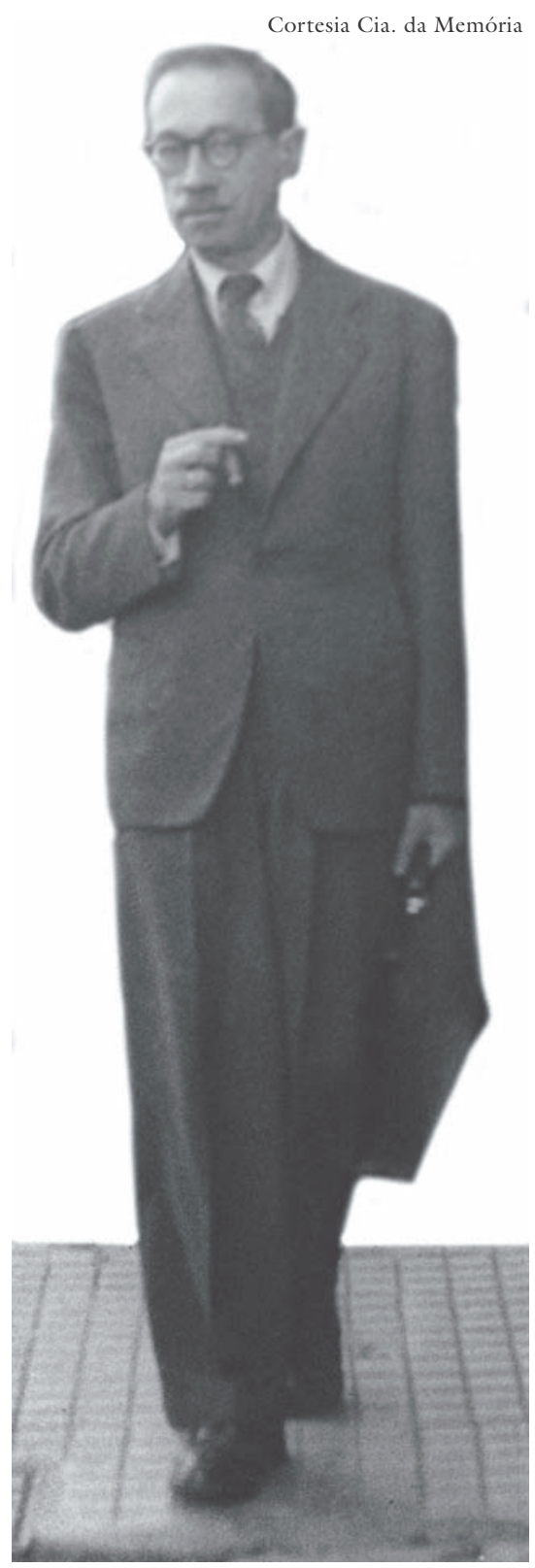


nunca chega lá, de algo que não se sabe o que é mas que me dá segurança e esperança, seria a essência da religião. Essa confiança, ao mesmo tempo perigosa e angustiante, em algo que não vejo e que não conheço, distingue-se da religião instituída em que os dogmas e os preceitos éticos concedem conforto e paz.

Podemos avançar mais nesta questão caminhando ainda com Desroche, agora relendo a introdução à primeira edição do seu dicionário de messianismos e milenarismos ${ }^{14}$.

Estamos trabalhando com os conceitos de religião e instituição, mas Desroche fala em sentimento religioso e religião como patamares distintos: aquele, a experiência religiosa antes da religião ou instituição. Creio que não há discrepância entre a proposta anterior e esta. Mas, não seria inconveniente observar que a experiência religiosa como simples sentimento nos remeteria mais a William James ${ }^{15}$ com sua proposta mais psicológica e subjetiva, ao passo que a experiência objetiva nos remeteria a Mircea Eliade, que parte do estudo das hierofanias. Entendemos, ainda, que ambas as propostas não se excluem, mas se completam.

No mesmo passo, Desroche desfila os autores que desenvolveram o tema de várias maneiras, mas que acabam convergindo para o sentido que buscamos. Assim desfilam as teorias de Durkheim (religião de efervescência e de administração), religião de primeira mão e religião de segunda mão (W. James), religião fechada e religião aberta (H. Bergson), e religiões vivas e religiões em conserva ( $\mathrm{R}$. Bastide).

O estudo sociológico dos messianismos e milenarismos empreendido por Desroche leva-o a registrar que o fato do sentimento religioso vivido, como ato efervescente, de primeira mão, invade a sociedade, ou o grupo religioso, em momentos de sobressalto da vida. As grandes religiões tradicionais, em momentos sociais de efervescência, ou também de grandes mudanças, que podem ser rápidas ou lentas, tendem a assumir posições que variam da indiferença a tentativas de ajuste ético, mas sempre preservando as posições dogmáticas tradicionais. Algumas com maior capacidade de ajustamento sem romper, ou enfraquecer, posições dogmáticas, se saem melhor, no máximo perdendo adeptos que, no todo, não lhes comprometem o futuro. Exemplo no Brasil foi a Igreja Católica no período dos militares e da Teologia da Libertação. Quanto ao protestantismo, nessa mesma circunstância, as perdas foram grandes porque sendo religião mais secularizada e leiga, o impacto de novas idéias políticas atingiu questões dogmáticas ao mesmo tempo rígidas e fracas quanto a centros de poder encarregados de sustentá-las.

Há, no protestantismo, particularmente na tradição reformada propriamente dita, um paradoxo permanente: ao mesmo tempo em que sustenta forte rigidez dogmática, seja por determinadas formas de interpretação da Bíblia, seja pelas formulações simbólicas consagradas em confissões de fé, falta-lhe centros de autoridade que definam pontos de divergência. Como conseqüência, são freqüientes os expurgos de pessoas e grupos que, por seu lado, reiniciam processos de institucionalização que desembocam em novas igrejas. 
Quanto maior for a rigidez dogmática, maior será a possibilidade de divergências no interior da religião instituída, ou igreja. Quando falamos em religião instituída como aquela que atingiu o máximo em sua construção dogmática, temos de considerar que esta religião formou poderosa elite intelectual capaz não somente de sustentar seus símbolos, mas também de oferecer alternativas quando estes símbolos são contestados.

Quando a contestação se dá no campo intelectual, os contestários são geralmente tolerados; no máximo são olhados com desconfiança pela ortodoxia e, vez por outra, sofrem pequenas advertências ou disciplinas. Neste caso, as querelas ainda laboram no campo do sagrado dominado. Os problemas surgem com maior gravidade quando pessoas ou grupos insatisfeitos com a rotina eclesiástica, ou acicatados por situações de efervescência social, decidem liberar o sagrado em favor de uma religião mais emocional que possa amenizar os impactos situacionais do cotidiano. As mudanças institucionais, regra geral, têm início, não por contestação intelectual, mas pela liberação ao menos parcial do sagrado através de formas emocionais de experiência religiosa.

Estudos consagrados, como os de Max Weber ${ }^{16}$ e Ernst Troeltsch ${ }^{17}$ mostram que as contestações de ordem emocional, que caminham como que num retrocesso em busca da recuperação do sagrado ao menos mais puro de um passado fundante tendem a formar grupos com pouca organização interna, assegurados por simples laços de comunhão. São chamados seitas. Mas, atingido um ponto máximo nesse retrocesso efervescente, tem início um processo gradativo de rotinização e organização dogmática cuja tarefa é assumida pelos intelectuais.

Voltamos a dizer que entre o sagrado instituinte da experiência religiosa e o instituído da instituição religiosa, há um gra-diente cujos segmentos mostram o grau de dominação do sagrado. A maneira de determinar em que ponto do gradiente certo grupo religioso se encontra é verificar o grau de intelectualização que atingiu, principalmente pela produção dogmática escrita, como também pelo grau de controle do sagrado nas reuniões religiosas ou cultos. Pode, todavia, haver casos em que o grupo religioso se recuse a produzir escritos ao expressar recusa ao labor intelectual, mas que apresentam certo grau de rotinização ou controle do sagrado ao mesmo tempo em que mantêm praxes e doutrinas por transmissão oral.

Duas grandes instituições religiosas brasileiras de perfil pentecostal podem servir de exemplo para o que estamos dizendo. Ambas tiveram início quase que ao mesmo tempo e em circunstâncias praticamente iguais. Tratam-se da Assembléia de Deus e da Congregação Cristã no Brasil, aquela surgida no norte do Brasil em 1911 e esta, no sul em 1910. Ambas fazem parte do que temos chamado de pentecostalismo clássico.

A Assembléia de Deus, ou Assembléias de Deus, pois que seguem a tradição batista de autonomia das congregações locais, começou com um movimento de experiência religiosa induzida por dois missionários sueco-americanos em uma 
igreja batista de Belém do Pará. Da experiência da posse do Espírito Santo com o sinal da glossolalia percorreram um longo caminho de institucionalização até chegar hoje a ocupar o lugar de maior igreja evangélica no Brasil. A não ser a ênfase ainda mantida na posse do Espírito, com certa liberação emotiva, principalmente nas orações, a Assembléia de Deus pouco se distancia das igrejas protestantes tradicionais. Possui uma teologia explícita calcada no metodismo wesleyano $^{18}$, isto é, na variante arminiana do calvinismo, textos teológicos, um jornal semanal vendido em bancas, assim como seminários para a educação de sua liderança. Em seus cultos, há um espaço limitado e controlado para o sagrado mais livre. É o seu único distintivo em relação às igrejas tradicionais pois que, no gradiente, está muito próxima delas.

A Congregação Cristã no Brasil inicia-se com a mesma experiência fundante da Assembléia de Deus e acabou fortemente institucionalizada. Talvez esta característica tenha seu fundamento no traço calvinista herdado de seu fundador, o valdense e depois presbiteriano nos Estados Unidos, Luis Francescon. A herança calvinista da CCB reflete-se bastante na ordem e na disciplina, tanto na vida privada como no culto, assim como na vida institucional. A forte institucionalização dessa igreja, ao que se observa, reduziu mais ainda o espaço para a ação livre do sagrado.

Dentro de um culto extremamente racionalizado, há dois momentos de liberdade: um é a abertura para qualquer membro da congregação tomar a iniciativa de ler a Bíblia e pregar, o outro é o momento de testemunho, ou "testemunhança" como eles preferem dizer. O testemunho é o espaço do culto em que qualquer pessoa pode relatar alguma experiência religiosa em sua vida. A liberdade de pregar, apesar de continuar a ser oferecida nos cultos, quase que não é mais aproveitada pelos adeptos que

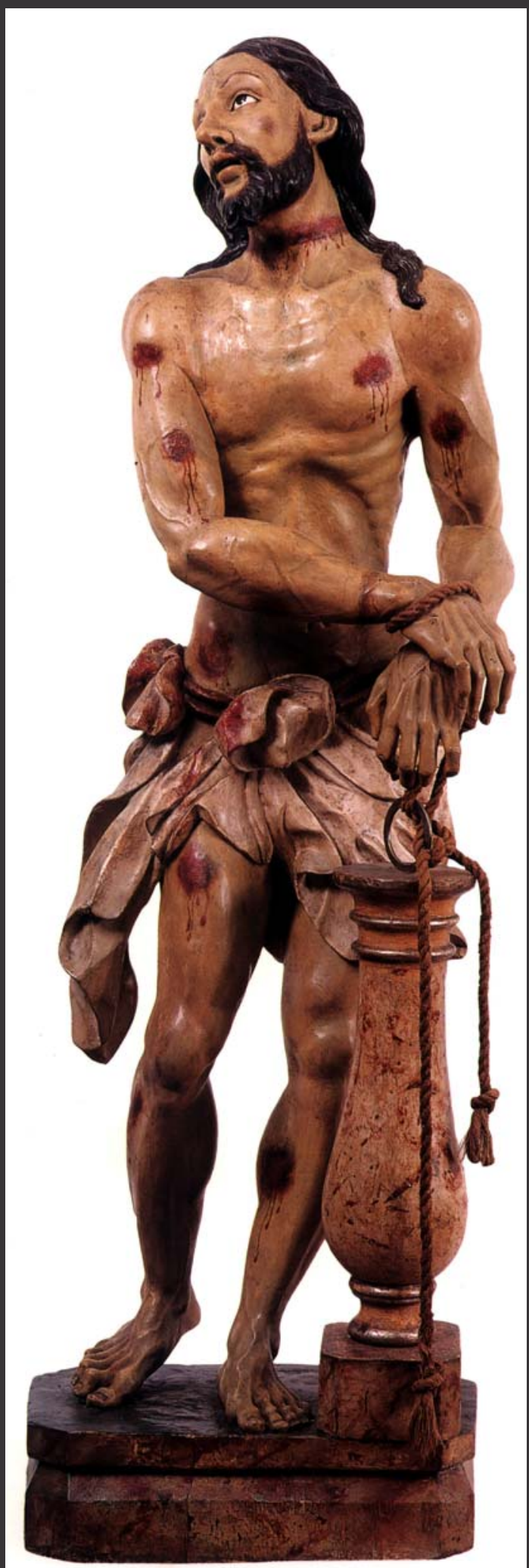

Cristo da Coluna, Manoel Inácio da Costa. 
preferem deixar a prédica por conta dos líderes. O testemunho é atentamente fiscalizado pelo líder à frente do culto que, ao notar irrelevância ou inconveniência no relato, tem a auto-ridade para interrompê-lo dizendo "não vem do Espírito".

A transmissão religiosa na CCB é exclusivamente oral eclesial (na igreja). Os únicos textos são a Bíblia, e ainda exclusivamente a versão de João Ferreira de Almeida Revista e Corrigida, o livro de hinos e o relatório anual de atividades da igreja. Circulou entre os membros da Igreja, ao menos até recentemente, um folheto com poucas páginas, de autoria do fundador Luís Francescon, uma narrativa de sua experiência religiosa. Este autor foi informado de que o folheto não estava mais sendo impresso porque muitas pessoas estavam tomando Francescon por santo e orando com sua intermediação.

Tanto uma como outra dessas igrejas, fortes no cenário religioso brasileiro, representam estágios diferentes no gradiente sagrado selvagem ou instituinte e sagrado dominado ou instituído.

\section{Experiência religiosa e institucionalização}

Tentamos expor as variações, tanto instituidoras como transformadoras, no campo representado pelo gradiente sagrado selvagem ou instituinte e sagrado dominado ou instituído.

Agora, caminhando para a conclusão deste texto, desejamos apresentar uma teoria que nos ajuda a resumir de forma clara tudo o que já foi exposto e discutido.

$\mathrm{O}$ autor desta teoria, que tomamos a iniciativa de denominar "teoria dos círculos concêntricos”, é Frederico Heiler (1892-1967), cientista da religião que começa a circular no Brasil recentemente através de Giovanni Filoramo e Carlo Prandi ${ }^{19}$. Suas obras tiveram circulação restrita, parecendo que com mais evidência na Itália, onde pelo menos sua obra principal Erscheinungsform und Wesen der Religion (1961) foi traduzida ${ }^{20}$.

Tenho tentado inteirar-me o melhor possível da teoria de Heiler sobre a fenomenologia da religião. Encontrei o melhor material em seu livro, o único ao que se sabe traduzido para o inglês, que é Das Gebet (1923). Quanto à sua obra principal, valho-me da excelente exposição de Peter Mckenzie ${ }^{21}$, The Christians, their Beliefs and Practices (1988).

A teoria dos círculos concêntricos permite-nos percorrer a trajetória, ou o gradiente sagrado-instituinte-sagrado-instituído, inclusive as diferentes formas de expressão individual e social da religião.

Suponhamos três círculos concêntricos. O primeiro, o exterior, revela parcialmente o objeto sagrado, as maneiras pelas quais o sagrado se revela no mundo empírico porque pode ser percebido pelos sentidos, fenomenologicamente nas "aparições" das condutas pessoais e nas instituições. São as maneiras ou formas pelas quais o sagrado se manifesta, principalmente nas instituições religiosas visíveis: templos, cultos, ritos, objetos sagrados etc. É o mundo do sagrado dominado, instituído. 
O círculo intermediário trata das concepções e idéias religiosas (teogonias ou teologias). É o lugar dos sistematizadores da experiência religiosa, dos dogmáticos e seus representantes e guardiões. É o espaço dos intelectuais da religião instituída. As efervescências que começam no círculo externo são controladas neste círculo, pois que elas tendem para o círculo central, lugar do sagrado puro ou instituinte.

O círculo central é, pois, o lugar do sagrado absoluto. É o mundo vivido da experiência religiosa. Este é o lugar dos místicos, dos ascetas. É o coração da religião, mas não é ainda a religião em si. $\mathrm{O}$ asceta, o místico, não tem religião alguma; só tem a posse parcial, limitada, do sagrado. Em resumo, quando o sujeito da experiência religiosa, partindo do círculo central chega ao intermediário, cria uma religião; quando parte do círculo externo, círculo dos leigos por excelência, ou do intermediário, círculo dos intelectuais e sacerdotes, e chega ao central, sai da religião.

O místico sai da religião porque na sua ascensão para o sagrado ele vai abandonando todas as formas de crença anteriores, assim como as sistematizações adquiridas. O místico contempla o sagrado sem intermediações e nisto se contenta.

\section{Conclusão}

Nosso intuito foi expor o duplo caminho, de ida e volta, entre a experiência religiosa psicológica ou hierofânica, se é que se pode separar uma da outra, à religião institucionalizada ou igreja, no caso do Cristianismo. Esse percurso, que constitui um gradiente, apresenta o sagrado como constituinte ou constituído e é, ao mesmo tempo, conservador e transformador da religião. E, por fim, através da teoria dos círculos concêntricos de Frederico Heiler, mostrar idealmente os campos específicos da religião, dedicando atenção especial à formação da religião como instituição e o caminho de saída da religião, modelarmente representado pela mística.

\section{Notas}

l Cadernos do Ceru, n. 7, out. 1974.

2 Idem, p. 9.

3 Herry Fosdick, The Man from Nazareth, New York, Pocket Books, 1953.

4 Tradução inglesa The Gospel and the Church, 1908, p. 115.

5 Rger Bastide, Le Sacré Sauvage et autres études, Paris, Payot, 1975.

6 Thomas J. J. Altizer e William Hamilton, Radical Theology and The Death of God, 1966

7 Rosino Gibellini, A teologia do século XX, 1998, p. 142.

8 Gabriel Vahanecin, The Death of God, 1961. 
9 J. A. T. Robinson, Honest to God, 1965.

10 Havey Cox, The Secular City, 1965 (A cidade do homem, São Paulo, 1971).

11 Robert Adolfs, Igreja, tomulo de Deus?, Rio de Janeiro, Paz e Terra, 1968.

12 IX, 1-17 (DK 22 A 1), em “Os Pré-Socráticos”, Coleção Os Pensadores, p. 83.

13 Rudolf Otto, O sagrado, S. Bernardo do Campo, Imprensa Metodista/ Instituto Ecumênico de Pós-Graduação em Ciências da Religião, 1985.

14 Dieux d'hommes - Dictionnaire des Messianismes et Millénarismes de l'Ère Chrétienne, 1969 (Dicionário de messianismos e milenarismos, São Bernardo do Campo, Universidade Metodista de São Paulo, 2000).)

15 The varieties of religious experience: a study in human nature, 1902

16 Max Weber, Economia e sociedade, vol. 1, 1991, pp. 310 e ss.

17 Ernst Troeltsch, The Social Teaching of the Christian Churches, vol. 2, London, George Allen \& Unwin Ltd./New York, The Macmillan Company, 1956, pp. 691 e ss.

18 De John Wesley (1703-1791), fundador do metodismo.

19 Giovanni Filoramo e Carlo Prandi, As ciências das religiões, São Paulo, Paulus, 1999, pp. 27 e ss.

20 Traduzido com o título Le religioni dell'umanità, 1985.

21 Peter Mckenzie, The Christians, their Beliefs and Practices, Nashville, Abingdon Press, 1988.

Bibliografia

ADOLFS, Robert. Igreja, túmulo de Deus? Rio de Janeiro, Paz e Terra, 1968.

ALTIZER, Thomas J. J. e HAMILTON, William. Radical Theology and The Death of God, 1966.

BASTIDE, Roger. Le Sacré Sauvage et autres essais. Paris, Payot, 1975.

BISHOP, J. A. T. Robinson. Honest to God, 1965.

Cadernos do Ceru-Centro de Estudos Rurais e Urbanos, n. 10, nov. 1977 (número dedicado a Roger Bastide).

COX, Harvey. The Secular City, 1965. Trad. em português Cidade do homem, São Paulo, Paz e Terra, 1971.

DESROCHE, Henri. Sociologia da esperança. São Paulo, Paulinas, 1985.

Dicionário de messianismos e milenarismos. São Bernardo do Campo, Universidade Metodista de São Paulo, 2000.

FILORAMO, Giovanni e PRANDI, Carlo. As ciências das religiões. São Paulo, Paulus, 1999.

FOSDICK, Harry E. The Man from Nazareth, New York, Pocket Books, 1953.

GIBELINI, Rosino. A teologia do século XX. São Paulo, Loyola, 1998.

MCKENZIE, Peter. The Christians. Nashville, Abingdon Press, 1988. 
Os Pré-Socráticos. Coleção Os Pensadores, São Paulo, Nova Abril Cultural, 1996.

OTTO, Rudolf, O sagrado, São Bernardo do Campo, Imprensa Metodista/ Instituto Ecumênico de Pós-Graduação em Ciências da Religião, 1985.

TROELTSCH, Ernst. The Social Teaching of the Christian Church London, George Allen \& Unwin Ltd./New York, The Macmillan Company, 1956.

VAHANIAN, Gabriel. The Death of God, 1961.

WEBER, Max. Economia e sociedade. Brasília, Editora UNB, 1991, vol. 1.

RESUMO - NA DINÂMICA do campo religioso brasileiro, grupos diferentes surgem constantemente, permanecendo alguns, desparecendo outros. Este trabalho constitui uma tentativa de mostrar como esses grupos situam-se num gradiente que caminha do momento inicial de um grupo até sua institucionalização final, seja em forma de igreja ou outra segundo sua maneira de instituir o sagrado. A referência teórica principal é o conceito de "sagrado selvagem" de Roger Bastide.

ABSTRACT - WITHIN the dynamics of the Brazilian religious milieu, different groups are constantly emerging - some remain, while others disappear. This essay is an attempt to show how these groups constitute a gradient, a continuum that stretches from their inception to their ultimate institutionalization, either as a church or in peculiar manners of institutionalizes sacredness. The main theoretical reference is Roger Bastide's concept of "savage sacredness".

Antonio Gouvêa Mendonça é doutor em Ciências Humanas pela Universidade de São Paulo e professor do Curso de Pós-Graduação em Ciências da Religião, Universidade Presbiteriana Mackenzie, São Paulo.

Texto recebido e aceito para publicação em 27 de agosto de 2004. 